\title{
Loss Analysis of Propulsion System on an Electric Railway
}

\author{
Agus Jamal $^{* 1}$, Anna Nur Nazilah Chamim ${ }^{1}$, Karisma Trinanda Putra ${ }^{1}$, Sri Indah Lestari ${ }^{1}$, Yessi \\ Jusman $^{2}$ \\ ${ }^{1}$ Department of Electrical Engineering, Faculty of Engineering, Universitas Muhammadiyah \\ Yogyakarta) \\ Bantul 55183 Daerah Istimewa Yogyakarta, Indonesia \\ ${ }^{2}$ Department of Informatics Engineering, Faculty of Engineering, Universitas Abdurrab \\ Pekanbaru, Riau, Indonesia \\ *Corresponding author, e-mail: agus_jamal@umy.ac.id
}

\begin{abstract}
Electric Railway (KRL) is a train that is based on eletrification system. The electrification system in the KRL supplies electrical energy to the train locomotive and several other carriage units, so the train can run. Electrical energy can be either AC or $D C$ source. There are two electrical systems to support the performance of KRL, propulsion system and auxiliary system. The propulsion system is a driving system and than the auxiliary system is the system that handles the electrical load on KRL. In this research, discuss about the loss of propulsion system on KRL LAA Electric DC, AC Traction Motor. The propulsion system consists of several components, such as pantograph, circuit breaker, capacitor filter, IGBT VVVF inverters and AC traction motors. The component has different losses and different efficiencies. There are five test conditions for AC traction voltage inputs of $160.5 \mathrm{~V}, 321 \mathrm{~V}, 493.9 \mathrm{~V}, 635 \mathrm{~V}$ and $645 \mathrm{~V}$. By calculating using equations, from the five test conditions it can be seen that the propulsion system has the lowest power loss with the highest efficiency at the input voltage of AC $635 \mathrm{~V}$ traction motors, which obtained the power loss of inverter VVVF IGBT $41.996 \mathrm{~kW}$ with the efficiency $90.67 \%$ and the power loss of AC traction motor $18.219 \mathrm{~kW}$ with the efficiency 91.45
\end{abstract}

Keywords: propulsion system, loss, pantograph, circuit breaker, capacitor filter, IGBT inverter VVVF, AC traction motor.

\section{Introduction}

Train is the government's choice in supporting transportation needs. Where, the train is land transportation that runs along the railroad track, consisting of a locomotive and a series of wide carriages so that it can nod passengers and goods on a large scale. "In big cities, both between cities, trains are an efficient mode of transportation available, which is cheap, because it must be prioritized for development," said President Jokowi while chairing a limited meeting, at the Presidential office, Jakarta, Monday (7/13) / 2015). Based on data from the Central Statistics Agency (BPS) in
December 2016 the number of train passengers was 32.2 million or an increase of $8.29 \%$ and the number of goods transported was recorded at 3.3 million tons or an increase of $4.38 \%$ compared to November 2016. From these data it can be seen that the increasing interest in utilizing mass transportation modes provided by the government can reduce traffic density, and can support the existing railroad industry in the country.

The mode of transportation of trains has actually been of interest to the public since Indonesia was not yet independent, one of which is the electric railroad (KRL) whose development began in 1925 . The KRL is a railroad that moves based on electric motor propulsion systems with a main source of 
1500 VDC electricity that is channeled through current flow top (catenary) and flowed to the KRL through pantographs. Seeing the increasing number of train passengers as well as the urgency of efficient transportation needs, the efficiency of the KRL must be paid attention to in order to create a maximum working system, especially on the KRL propulsion system which acts as a KRL driver. With an efficient drive system, it can be an answer to the above problems, that an efficient KRL is very much needed by the community in each of its activities so that the punctuality of departure and arrival time is as scheduled or does not experience a setback.

To support the performance of the propulsion system, several electrical components are needed, namely the VVVF IGBT inverter and the traction motor as a drive. Both components have different efficiencies. As with the electrical system, from the source of the generator to the burden of power losses, the KRL from the input source to the propulsion system also has power losses. The power losses must be kept to a minimum in order to improve the efficiency of the KRL propulsion system. Therefore, to find out the efficiency of the KRL propulsion system performance, the magnitude of power losses for each component of the propulsion system need to be calculated.

Jin Wang, Zhongping Yang, Fei Lin and Junci Cao. with the title "Harmonic Loss Analysis of Traction Transformers of High-Speed Trains Considering Pantograph-OCS Electrical Contact Properties", in his research stated that the contact cable and pantograph are not directly connected, but both will be connected and interact with each other when the KRL is moving [1].

Achmad Efendi Setiawan, Tjahya Odinanto and Syahri Muharom (2016) with the research title Design of 3 Phase Inverter as Speed Control of 3 Phase 1 / 2HP Induction Motor 0.37 KW using SPWM Method based on Mirocontroler (STM32F4). Where in this study, a motor is controlled by an inverter with SPWM control in order to find the difference between the estimated frequency and the reference frequency. The results of the study stated that the magnitude of the error generated in the design was $0.6 \%$ with a set point of 300rpm [2].

S. Cornio E. Romero L.F Mantila (2008) with the research title How the Efficiency of Induction Motor is Masured?. In this study discusses the measurement of the efficiency of induction motors by comparing three standards of induction motor efficiency calculations namely IEEE 112, IEC 60034-2 and JEC-37. Where from the results of these studies obtained results that the magnitude of efficiency in each standard has a different value [3].

The purpose of this study is to determine the magnitude of losses and efficiency in each component of the propulsion system on KRL.

\section{Methods}

Flowchart for the research is presented in Fig. 1.

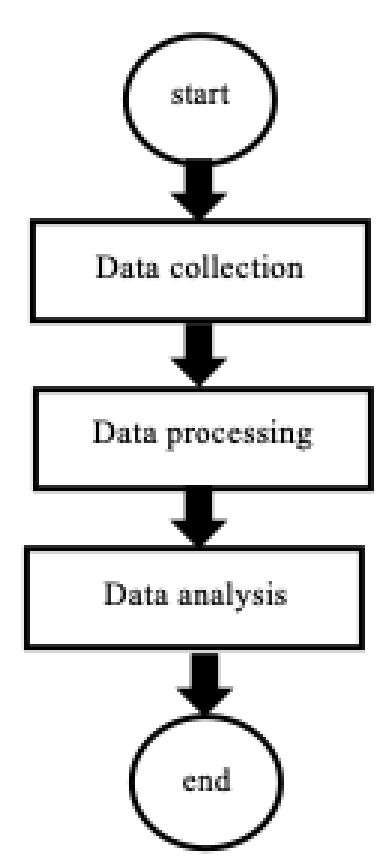

Fig. 1. Flowchart

\section{Data collection}

Data collection is done by finding information and data related to the KRL propulsion system, such as the amount of voltage supply on the KRL, the components of the propulsion system and its specifications.

\section{Data processing}

When the data has been obtained, the next step is data processing, where the data is processed by manual calculation.

\section{Data analysis}

After processing the data, new parameters will appear that result from data processing. The results of data processing in the form of the amount of losses and efficiency in each component of the propulsion system on KRL. The amount of efficiency of each propulsion system supporting component can be used as a reference in the design and improvement of the propulsion system on KRL. 


\section{Results}

\section{III.1. KRL Specifications}
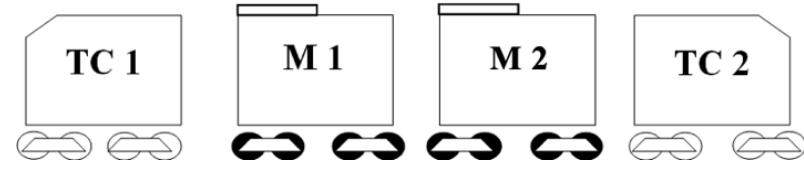

Fig. 2. A set of KRL

Figure 2 is a series of KRL sets, where there are four cars namely $\mathrm{TC} 1, \mathrm{M} 1, \mathrm{M} 2$ and TC2. TC (Trailer Cabin) is a car without a driving machine, while $\mathrm{M}$ (motor) is a car with a driving machine and is equipped with a pantograph. The pantograph is located on the roof of M1 and M2 carriages arranged in parallel. The KRL set is divided into two units, the first unit consisting of TC1 and M1 while the second unit consists of TC2 and M2. Each unit has a complete propulsion system. The layout of each KRL car is presented in Figures 3, 4, 5 and 6.

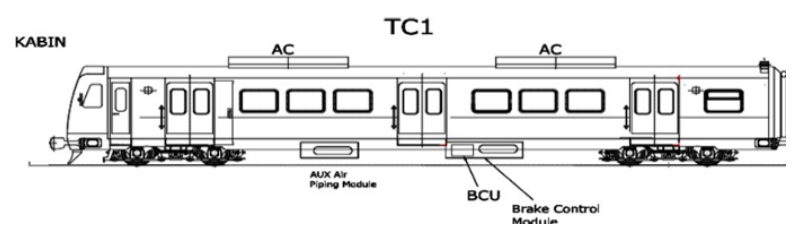

Fig. 3. TC1 carriage layout

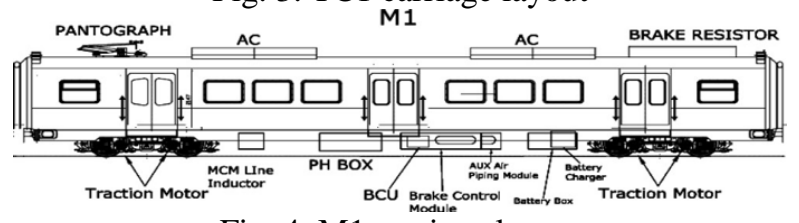

Fig. 4. M1 carriage layout

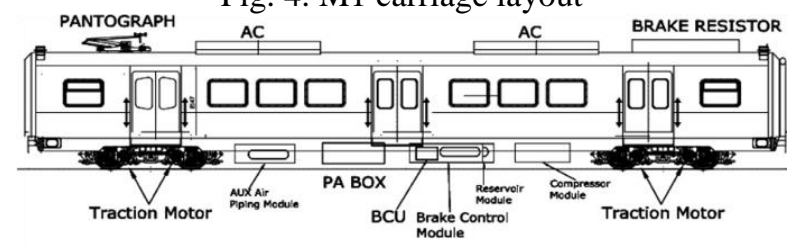

M2

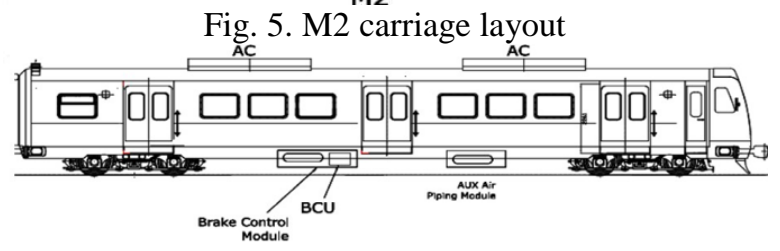

TC2

Fig. 6. TC2 carriage layout

From Figures 3, 4, 5 and 6, it can be seen that the propulsion system on the KRL is on M1 and M2, each of which has a pantograph and four AC traction motors. To control the speed of the traction motor, an inverter is needed, which one inverter usually controls two AC traction motors. In this research, the M1 and M2 propulsion system losses are calculated where the M1 losses are equal to M2. The specifications of KRL are as presented in Table I.

TABLE I

PROPULSION SySTEM SPECIFICATIONS ON KRL

\begin{tabular}{cc}
\hline \hline Component Name & Specification \\
\hline Input Voltage & $1500 \mathrm{VDC}$ \\
Input Current & $1200 \mathrm{~A}$ \\
Input Power & $1800 \mathrm{~kW}$ \\
Type of IGBT & $3300 \mathrm{~V} / 1500 \mathrm{~A}$ \\
Capacitor & $4 \mathrm{mF}$ \\
AC traction motor & $200 \mathrm{~kW}$ \\
Speed & $100 \mathrm{~km} / \mathrm{h}$ \\
\hline \hline
\end{tabular}

\section{III.2. KRL Power Supply}

The power supply on the Electric Train (KRL) is obtained from the PLN $150 \mathrm{kV}$ substation which is reduced to a PLN $20 \mathrm{kV}$ electricity network by a $150 \mathrm{kV} / 20 \mathrm{kV}$ step down transformer. The $20 \mathrm{kV}$ voltage is still reduced again to $1200 \mathrm{VAC}$ by a $20 \mathrm{kV} / 1200 \mathrm{~V}$ step down transformer, which is then supplied to the rectifier. The rectifier here serves to convert the $1200 \mathrm{VAC}$ voltage into direct current (DC) electricity with a nominal voltage of 1500 VDC which is channeled to the upper channel (catenary) and forwarded to the train using a pantograph.

\section{III.3. KRL Propulsion System}

The propulsion system is a driving system on KRL that uses an AC traction motor as the main driver. Propulsion systems on KRL are on M1 and M2 so that there are two propulsion system units. Some of the components of the propulsion system in KRL include:

a. Pantograph as a channel of electricity from LAA to KRL,

b. Circuit Breaker (CB) as a breaker of electricity in the event of an error or disturbance,

c. Capacitors function as energy storage in an electric field with collect energy imbalances in the electric field, as well as a filter to suppress noise in the output voltage waveform or refine the output voltage waveform,

d. VVVF IGBT inverters as single-phase DC 
power converters into three-phase AC electricity, as well as control motor speed by varying the voltage and frequency. The inverter output voltage varies, while the inverter input voltage is constant,

e. AC traction motor as a drive, where the threephase supply voltage is obtained from the VVVF IGBT inverter.

The block diagram of the propulsion system on KRL is presented in Figure 7.

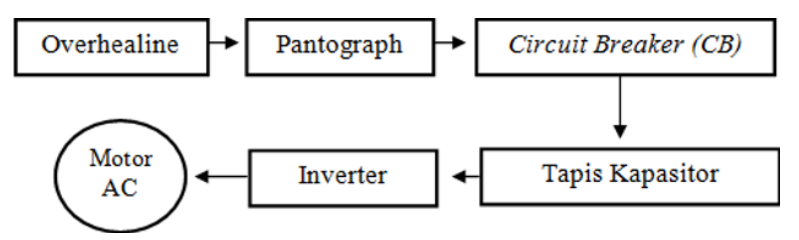

Fig. 7. Block diagram of propulsion system on KRL

From Figure 7, it can be seen that the KRL input power is obtained from the overheadline which is channeled to the KRL through the pantograph. To get to the $\mathrm{AC}$ motor, the power from the pantograph is channeled to several components of the propulsion system namely $\mathrm{CB}$, filter capacitors and inverters. Components of the propulsion system have their respective functions, as explained in the description above so as to have different efficiencies. Therefore, the magnitude of power losses in each component is certainly different.

In this paper, we will discuss the losses of each component of the propulsion system on KRL. The losses for each component of M1 are the same as $\mathrm{M} 2$, because the M1 and M2 propulsion systems are the same. For more details, the series of each $M$ propulsion system on KRL can be seen in Figure 8 .

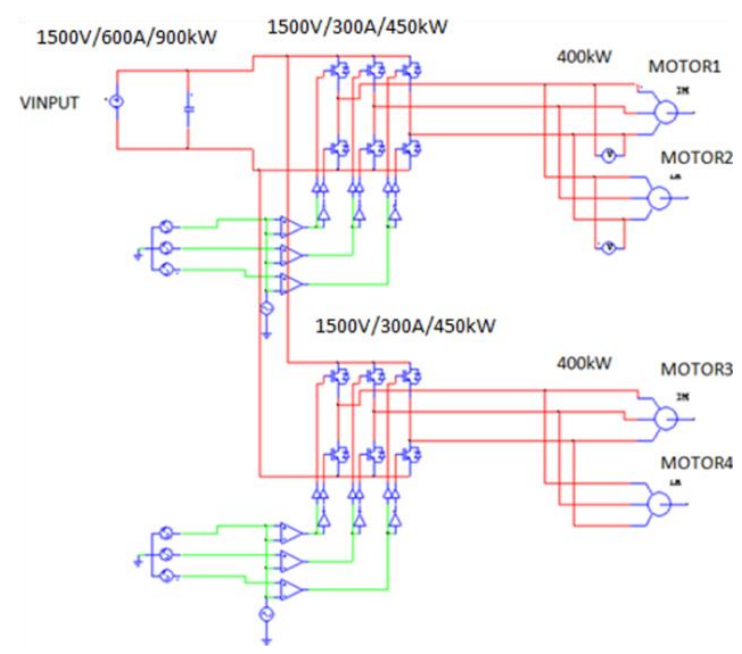

Fig. 8. KRL propulsion system circuit on each motor (M)
Basically, KRL can run if it receives electricity supply as its energy source. The supply of electrical energy is obtained from the upper channel or catenary which is channeled through the pantograph. The power is obtained from the sliding contact between the slides of the pantograph and the contact cable. When the pantograph passes through catenery, there is a dynamic interaction between the pantograph and the catenary. As speed increases, the vibrations caused by the pantograph and catenary get bigger, causing the pantograph to slide away from the contact cable and can cause arcs and sparks.

Arcs and sparks are very influential on the amount of voltage that is channeled to support the performance of the KRL propulsion system itself. In addition, it can also cause KRL to lose direct contact which will cause interference with the power supply which can interfere with the KRL traction system.

Regarding the analysis of pantograph losses, the study uses a pantograph-catenary system created using MSC software [1]. The contact cable and the pantograph are not directly connected, but both will be connected and interact with each other when the KRL is moving. Pantograph and catenary are connected by lift force and contact pressure, so the relationship between pantograph and catenary can result in loss of power. In this study, research was conducted on pantograph losses using the pantograph and catenary models as presented in Figure 9.

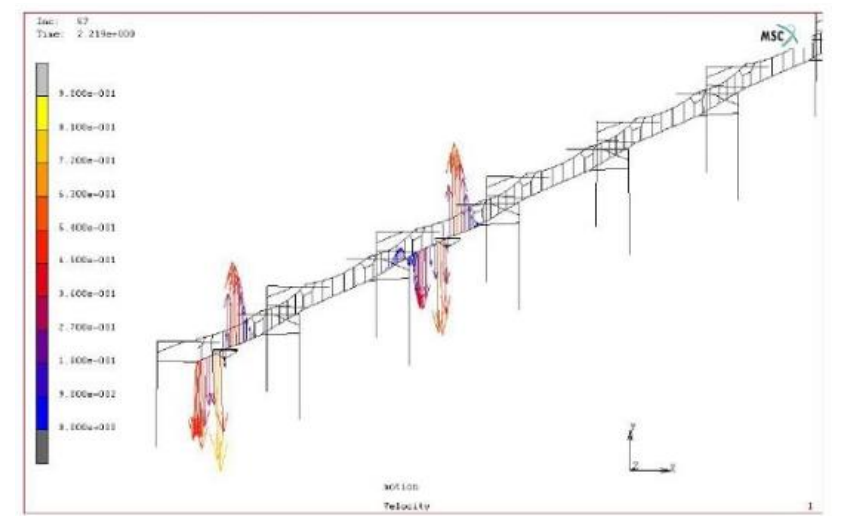

Fig. 9. A model of a cathedral and a catenary

In this study, pantograph losses with four KRL speed conditions are $250 \mathrm{~km} / \mathrm{h}, 350 \mathrm{~km} / \mathrm{h}, 400$ $\mathrm{km} / \mathrm{h}$ and $450 \mathrm{~km} / \mathrm{h}$ and the following output waves are obtained; 


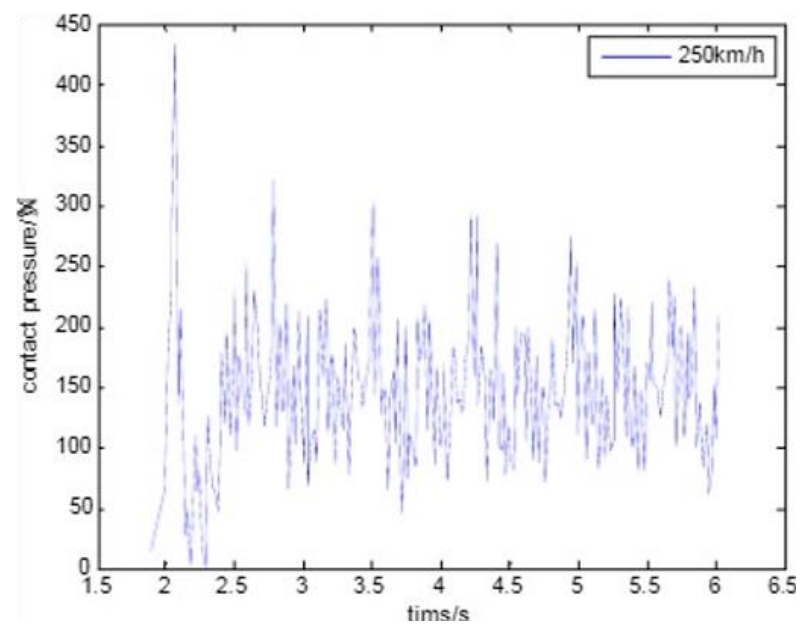

Fig. 10. Speed of $250 \mathrm{~km} / \mathrm{h}$

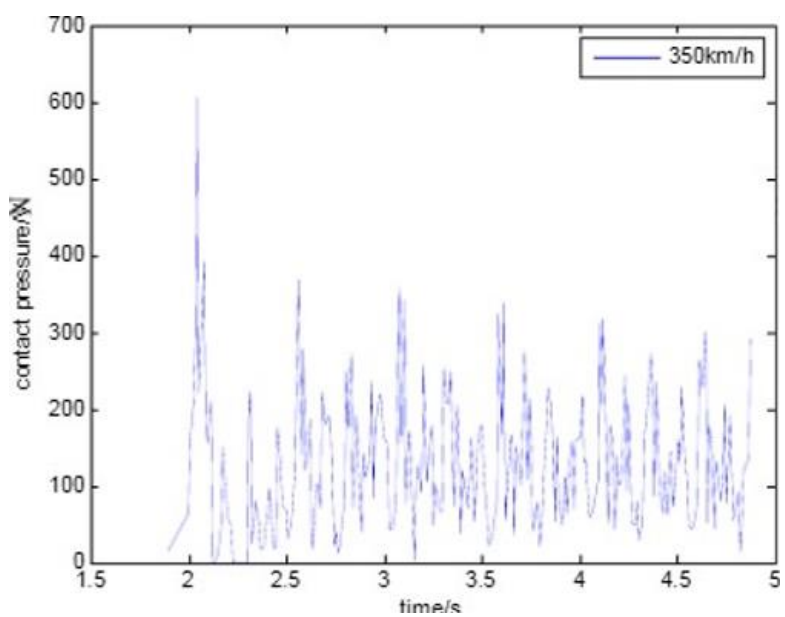

Fig. 11. Speed of $350 \mathrm{~km} / \mathrm{h}$

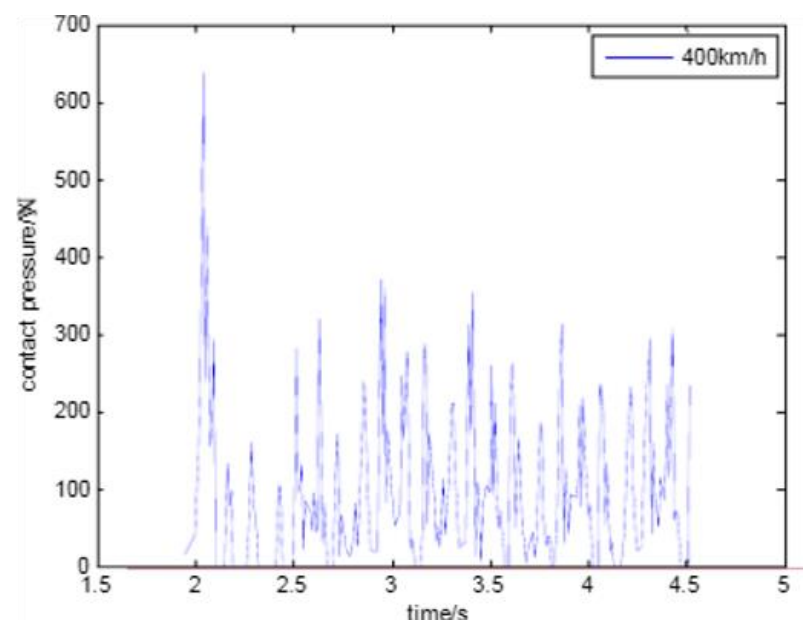

Fig. 12. Speed of $400 \mathrm{~km} / \mathrm{h}$

From Figures 10, 11, 12 and 13, different loss results are obtained, as shown in Table 5. Where, the total time is the total time (ttotal) of the simulation except for the time the pantograph increases. Disconnection time (tloss) is the amount of time at each break with a force of $0 \mathrm{~N}$. Ttotal minus tloss is the contact time (tcontact). Contact pressure greater than $0 \mathrm{~N}$ as long as the contact is connected. Therefore, the cut off ratio can be expressed as ploss (ploss $=$ tloss divided by ttotal $)$.

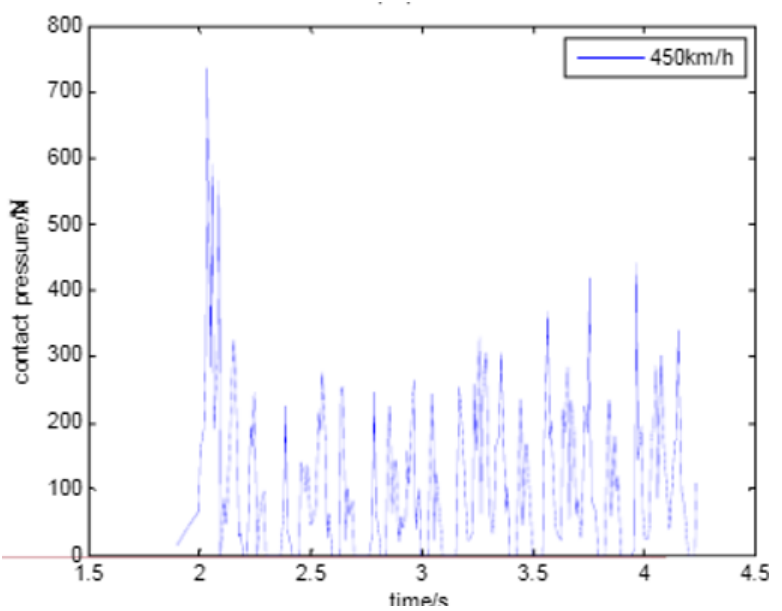

Fig. 13. Speed of $450 \mathrm{~km} / \mathrm{h}$

The four waveforms can be seen that the number of points with the contact pressure curve equaling 0 increases with increasing speed, which indicates that the number of breaks is not greater than $5 \%$. The Table II shows that ploss is less than $5 \%$ at speeds below $350 \mathrm{~km} / \mathrm{h}$ and with a breakdown ratio greater than $20 \%$ at speeds of $40 \mathrm{~km} \mathrm{/} \mathrm{h.}$ Termination ratio of $20 \%$ must be avoided.

TABLE II

SPEED RELATIONSHIP WITH PLOSS

\begin{tabular}{ccccc}
\hline \hline $\begin{array}{c}\text { Speed } \\
(\mathrm{km} / \mathrm{h})\end{array}$ & $\begin{array}{c}\text { Tloss } \\
(\mathrm{s})\end{array}$ & $\begin{array}{c}\text { Tcontact } \\
(\mathrm{s})\end{array}$ & $\begin{array}{c}\text { Ttotal } \\
(\mathrm{s})\end{array}$ & $\begin{array}{c}\text { Ratio of } \\
\text { disconnection } \\
\text { ploss }(\%)\end{array}$ \\
\hline 250 & 0.018 & 4.112 & 4.13 & 0.44 \\
350 & 0.103 & 2.877 & 2.98 & 3.45 \\
400 & 0.551 & 2.018 & 2.57 & 21.45 \\
450 & 0.670 & 1.670 & 2.34 & 28.63 \\
\hline \hline
\end{tabular}

From Table II, it can be seen that the faster the KRL goes, the greater the resulting ploss will be. In other words, the amount of KRL speed is directly proportional to the amount of ploss. The relationship between the two can be illustrated in Figure 14.

Pantographic losses are mechanical losses because they are related to the speed of the train, so the author does not include the magnitude of pantographic losses in this study.

The capacitor in the KRL propulsion system circuit acts as a filter circuit which serves to suppress the ripple voltage. By pressing the ripple, 
the resulting output wave is smoother. As in the circuit above, where the input voltage is DC then with this filter capacitor the true output voltage can be maintained in the same direction, because the ripple voltage can pass the components in the same direction and prevent component back and forth.

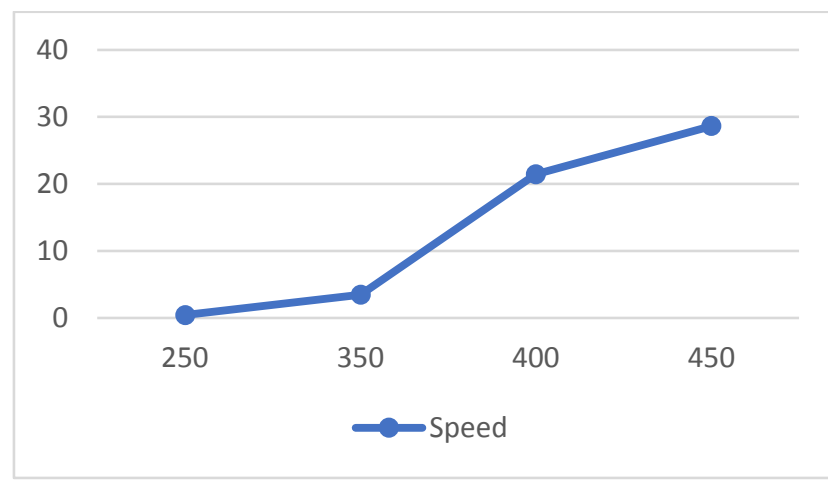

Fig. 14. The relationship between speed and ploss

This can happen because the capacitor will store the voltage when the source voltage rises. Where, when the source voltage rises the capacitor will be filled to the maximum voltage. Meanwhile, when the voltage source decreases, the capacitor will release the energy stored to the load. Designing a capacitor filter is quite easy, just by connecting the capacitors with the load in parallel. The amount of power before and after passing through the capacitors is different, because by using filter capacitors there are power losses. Power loss filter capacitors associated with mechanical losses so the authors do not include the losses of filter capacitors in this study.

\section{Losses of VVVF IGBT}

Inverters VVVF IGBT Inverters consist of six IGBT switches or switches which are mounted parallel. Inside the IGBT there are diodes, each mounted in parallel between one diode with the other. IGBT is controlled by PWM, where one PWM can control two IGBTs. IGBT is an active semiconductor which is the main component in an inverter.

VVVF IGBT inverter functions as a single-phase DC voltage converter to a three-phase AC and as an $\mathrm{AC}$ traction motor speed control by changing the voltage and frequency values in the inverter to produce the desired output voltage and frequency. To obtain the desired voltage and frequency, the DC voltage or the input voltage is chopped by the carrier frequency. The inverter output voltage is used to supply the traction motor. The amount of the output voltage of the inverter is influenced by the magnitude of the input voltage and PWM voltage which is the result of modulation between the carrier signal and the reference signal.

When the reference voltage is smaller than the carrier voltage, the output voltage generated by the inverter will be small. Vice versa, if the reference voltage is greater than the carrier voltage, the resulting output voltage will be greater. A series of three-phase IGBT VVVF inverters is presented in Figure 15.

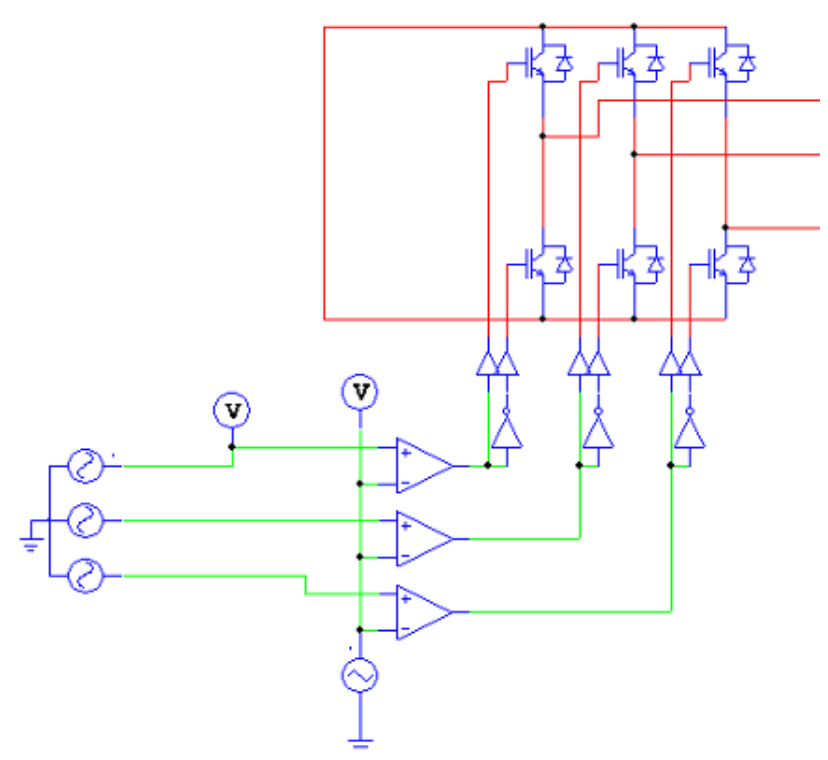

Fig. 15. Three-phase inverter series with PWM control

To find out the magnitude of losses on the inverter, a calculation with five conditions is performed, the condition is obtained from the results of motor testing. As explained above, that the inverter is composed of six IGBT which in the IGBT there are diodes, each arranged in parallel with the other diode. So that the losses on the inverter are influenced by losses contained in IGBT and diodes.

\section{a. IGBT Losses}

In IGBT, there are two types of losses, namely conduction losses and switching losses or switching losses. Conduction losses are caused by the voltage drop on the IGBT, where the voltage is affected by the current, so conduction losses are the product of the voltage on the current flowing. The on voltage is the voltage of one constellation collector while the current flowing is the collector current. For the use of PWM control, the magnitude of conductance loss can be sought by multiplying between one 
collector's collector, collector current and duty cyecle (D), where in the equation it is known that to find $\mathrm{D}$ with the following equation 1 .

$$
D=\left(V_{r} / V_{c}\right)
$$

While switching losses are losses that depend on the voltage, current flowing and switching time of the switch. Switching losses are divided into two, when switching on and switching off. When switching on, the amount of losses depends on the current and voltage that passes through the switch. In contrast to swiching off losses, when switching off the magnitude of losses is smaller than switching on, it does not even need to be taken into account. This is because the losses that arise are relatively small due to the leakage current flowing at the switch a little. However, in this research the switching off losses are calculated.

The inverter uses HiNAAK IGBT 5SNA $1500 \mathrm{E} 330305$ with a $\mathrm{V}_{\mathrm{CE}}$ of $3300 \mathrm{~V}$ and $\mathrm{I}_{\mathrm{C}}$ $1500 \mathrm{~A}$. The following is a calculation of the amount of power on $\left(E_{\text {on }}\right)$ and power off $\left(E_{\text {off }}\right)$ used to find the amount of losses on an inverter with five conditions as presented in Table III.

TABLE III

CAlculation Parameters For POWER ON AND POWER OFF

\begin{tabular}{cc}
\hline \hline Working Area & Value \\
\hline $\mathrm{V}_{\text {geon }}$ & $15 \mathrm{~V}$ \\
$\mathrm{R}_{\text {gon }}$ & $1 \Omega$ \\
$\mathrm{V}_{\text {geoff }}$ & $15 \mathrm{~V}$ \\
$\mathrm{R}_{\text {geoff }}$ & $1.5 \Omega$
\end{tabular}

Switching power on,

$$
\begin{aligned}
& \mathrm{E}_{\text {on }}=\left(\mathrm{V}_{\mathrm{ge}}{ }^{2} / \mathrm{R}_{\text {gon }}\right) \\
& \mathrm{E}_{\text {on }}=\left(15^{2} \mathrm{~V} / 1 \mathrm{Ohm}\right) \\
& \mathrm{E}_{\text {on }}=225 \mathrm{~W} \\
& \text { Switching power off }, \\
& \mathrm{E}_{\mathrm{on}}=\left(\mathrm{V}_{\mathrm{ge}} 2 / \mathrm{R}_{\mathrm{gon}}\right) \\
& \mathrm{E}_{\text {on }}=\left(15^{2} \mathrm{~V} / 1.5 \mathrm{Ohm}\right) \\
& \mathrm{E}_{\text {on }}=150 \mathrm{~W}
\end{aligned}
$$

From equation 2, the amount of switching on is $225 \mathrm{~W}$ and switching off is $150 \mathrm{~W}$. To find the magnitude of the duty cycle, the reference voltage, carrier voltage, reference frequency and carrier frequency must be adjusted to the PWM control. This setting refers to the use of analog PWM, where when the reference voltage is less than the carrier voltage, the resulting AC output voltage will be smaller than the DC input voltage, and vice versa when the reference voltage is greater than the carrier voltage, then the output AC voltage The output is greater than the DC input voltage. The following is a reference voltage regulation and carrier voltage with an output voltage value that is smaller than the DC input voltage.

1. Output voltage of $160.5 \mathrm{~V}$

To produce an AC output voltage of $551 \mathrm{~V}$, the reference signal's amplitude is $0.0505 \mathrm{~V}$ with a frequency of $20 \mathrm{~Hz}$. While the carrier signal amplitude is $4 \mathrm{Vpp}$ with a frequency of $200 \mathrm{~Hz}$. Each phase of the reference signal is $120^{\circ}$ different.

\section{Output voltage of $321 \mathrm{~V}$}

To produce an AC output voltage of $435 \mathrm{~V}$, the reference signal's amplitude is $0.198 \mathrm{~V}$ with a frequency of $20 \mathrm{~Hz}$. While the carrier signal amplitude is $4 \mathrm{Vpp}$ with a frequency of $200 \mathrm{~Hz}$. Each phase of the reference signal is $120^{\circ}$ different.

3. Output voltage of $493.9 \mathrm{~V}$

To produce an AC output voltage of $335 \mathrm{~V}$, the reference signal's amplitude is $0.475 \mathrm{~V}$ with a frequency of $20 \mathrm{~Hz}$. While the carrier signal amplitude is $4 \mathrm{Vpp}$ with a frequency of $200 \mathrm{~Hz}$. Each phase of the reference signal is $120^{\circ}$ different.

\section{Output voltage of $635 \mathrm{~V}$}

To produce an AC output voltage of $635 \mathrm{~V}$, the amplitude of the reference signal is $0.793 \mathrm{~V}$ with a frequency of $20 \mathrm{~Hz}$. While the carrier signal amplitude is $4 \mathrm{Vpp}$ with a frequency of $200 \mathrm{~Hz}$. Each phase of the reference signal is $120^{\circ}$ different.

5. Output voltage of $645 \mathrm{~V}$ output voltage

To produce $235 \mathrm{~V}$ AC output voltage, the reference signal amplitude is $0.8222 \mathrm{~V}$ with a frequency of $20 \mathrm{~Hz}$. While the carrier signal amplitude is $4 \mathrm{Vpp}$ with a frequency of $200 \mathrm{~Hz}$. Each phase of the reference signal is $120^{\circ}$ different. With the magnitude of the output voltage above, we obtain IGBT losses in a constellation with the highest temperature of $150{ }^{\circ} \mathrm{C}$, as presented in Table IV. 
TABLE IV

LOSSES ON IGBT

\begin{tabular}{cccccc}
\hline \hline \multirow{2}{*}{ Working Area } & \multicolumn{5}{c}{ Conditions } \\
\cline { 2 - 6 } & 1 & 2 & 3 & 4 & 5 \\
\hline Vref & $0.0505 \mathrm{~V}$ & $0.198 \mathrm{~V}$ & $0.475 \mathrm{~V}$ & $0.793 \mathrm{~V}$ & $0.8222 \mathrm{~V}$ \\
Vcarrier & $4 \mathrm{~V}$ & $4 \mathrm{~V}$ & $4 \mathrm{~V}$ & $4 \mathrm{~V}$ & $4 \mathrm{~V}$ \\
Voutput & $160.5 \mathrm{~V}$ & $321.0 \mathrm{~V}$ & $493.9 \mathrm{~V}$ & $635.0 \mathrm{~V}$ & $645.0 \mathrm{~V}$ \\
Pinput & $450 \mathrm{~kW}$ & $450 \mathrm{~kW}$ & $450 \mathrm{~kW}$ & $450 \mathrm{~kW}$ & $450 \mathrm{~kW}$ \\
Losses & $40.946 \mathrm{~kW}$ & $21.749 \mathrm{~kW}$ & $16.662 \mathrm{~kW}$ & $16.046 \mathrm{~kW}$ & $16.118 \mathrm{~kW}$ \\
Poutput & $409.054 \mathrm{~kW}$ & $428.251 \mathrm{~kW}$ & $433.338 \mathrm{~kW}$ & $433.954 \mathrm{~kW}$ & $433.882 \mathrm{~kW}$ \\
Efficiency & $90.90 \%$ & $95.17 \%$ & $96.00 \%$ & $96.43 \%$ & $96.42 \%$ \\
\hline \hline
\end{tabular}

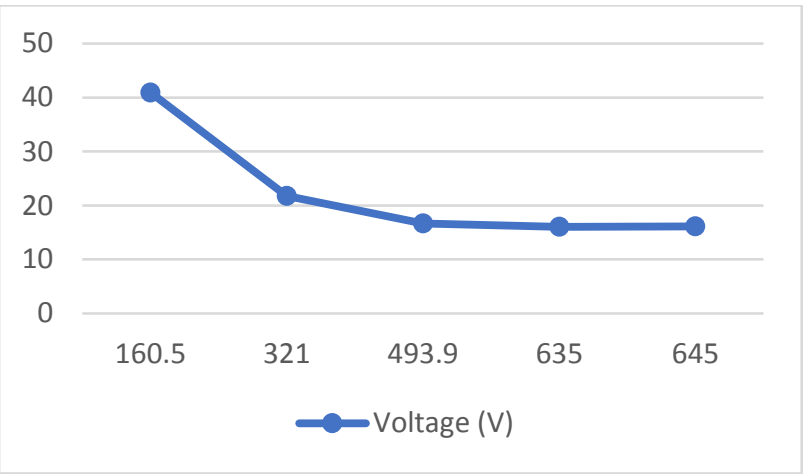

Fig. 16. Graph of the relationship between output voltage and losses

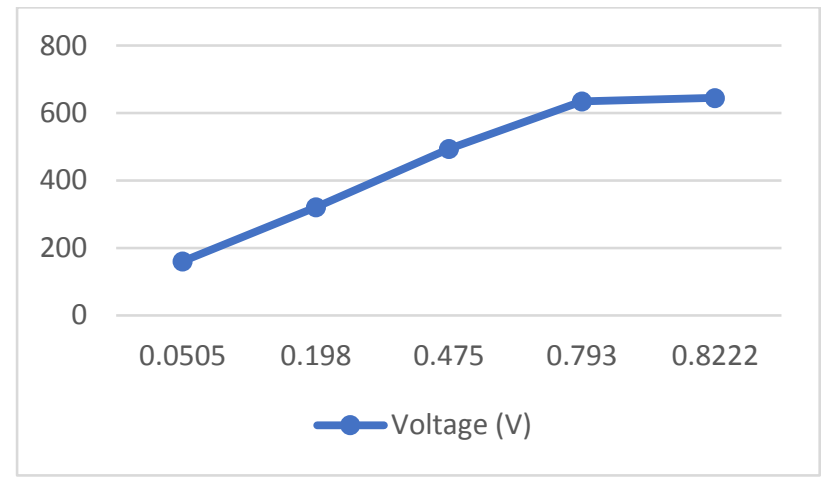

Fig. 17. Graph of the relationship between the output voltage and the reference voltage

From the Table IV, input power and output power in five inverter conditions obtained a very large efficiency that is above $90 \%$. Based on data from the Fuji Electric Journal states that for electric vehicles, where motorcycles that act as movers and power plants can take into account the higher proportion of vehicles by minimizing losses. To minimize these losses, Fuji Electric has developed IGBT which has a voltage resistance of $650 \mathrm{~V}$ with a lower loss.

The amount of losses is inversely proportional to the desired output voltage value, in other words the greater the output voltage, the greater the loss will be. This is in accordance with the equation $\mathrm{P}=\mathrm{I}^{2} \mathrm{R}$. A graph of the relationship between the output voltage and IGBT losses is presented in Figure 16.

The amount of output voltage is influenced by the reference voltage, carrier voltage, reference frequency and carrier frequency. In this calculation the magnitude of the carrier voltage and the carrier frequency are the same in each experiment, $4 \mathrm{~V}$ and $200 \mathrm{~Hz}$. The carrier frequency or carrier frequency functions as the switching frequency on IGBT. Meanwhile, the control is made changes to the reference voltage.

From the calculation results Table IV, it can be seen that the greater the reference voltage, the resulting output voltage is also greater. The use of this reference voltage is based on PWM control, where in the PWM circuit there is a comparator, when the reference voltage is 
greater than the carrier voltage, the resulting AC output voltage will be higher than the DC input voltage, whereas if the reference voltage is smaller than the carrier voltage then the AC output voltage produced will be lower than the DC input voltage. For more details, you can see in the graph the relationship between the reference voltage and the output voltage. A graph of the relationship between the two is presented in Figure 17.

The magnitude of the output voltage also affects the amount of efficiency. The highest efficiency is at $645 \mathrm{~V}$ output voltage that is $96.42 \%$ with losses of $16.118 \mathrm{~kW}$, while the lowest efficiency is at $160.05 \mathrm{~V}$ output voltage that is $90.90 \%$ with losses of $40.946 \mathrm{~kW}$. From condition one to condition five, it can be seen that the magnitude of the output voltage is directly proportional to efficiency. The greater the voltage, the smaller the current that flows so that the magnitude of the power will be small, according to the equation $\mathrm{P}=\mathrm{I}^{2} \mathrm{R}$. Neither is the opposite, when the voltage is small then the current flowing will be greater so that the magnitude of the power is large. With the equation $\mathrm{P}=\mathrm{I}^{2} \mathrm{R}$, where the current used is the result of the square of the current, so for largevalue currents, the current that flows will also be even greater.

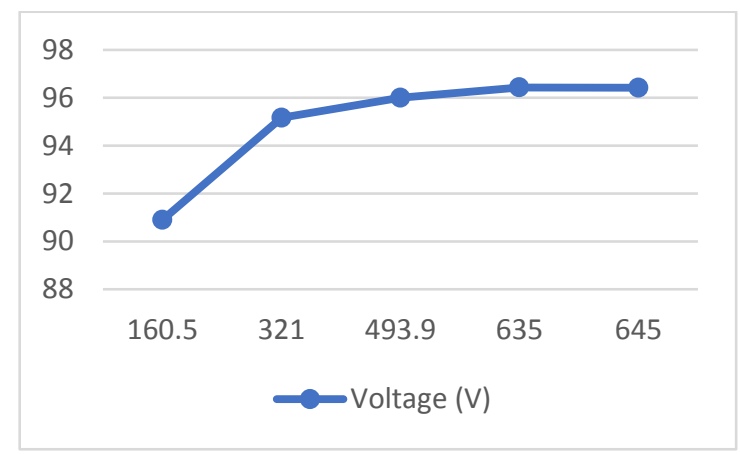

Fig. 18. Graph of relationship between inverter output voltage and IGBT efficiency

In switching losses, peak current or peak current $\left(\mathrm{I}_{\mathrm{pk}}\right)$ is very influential. $\mathrm{I}_{\mathrm{pk}}$ is the largest current of each event, in this study the peak current is obtained from the division between the input power and the $\mathrm{AC}$ output voltage in $\left(\mathrm{I}_{\mathrm{pk}}=\right.$ $\left.\left(\mathrm{P}_{\text {in }} / \mathrm{V}_{\text {out }}\right)\right)$. The magnitude of the value obtained in a three-phase state, so as to make the current value so that it is worth one phase, the current value is divided by $3\left(\mathrm{I}_{\mathrm{pk}}=\left(\mathrm{I}_{\mathrm{pk}} / 3\right)\right)$. The currents of each phase are assumed to be the same magnitude, because there are no direct measurements either through simulation or physically.

A graph of the relationship between output voltage and efficiency is presented in Figure 18.

\section{b.Diode losses}

In diodes there are two losses namely conduction loss and reverse recovery loss. Diodes are two-terminal P-N junction devices, namely anodes and cathodes which allow direct inrush or called conduction states, and current blocking conditions that occur when diode conditions are on to off or called reverse. These two conditions give rise to losses called conduction losses and reverse recovery losses. The following is the result of calculating losses on the diode as presented in Table V.

TABLE V

Diode Loss CALCULATION RESUlts

\begin{tabular}{cccc}
\hline \hline $\begin{array}{c}\text { Vout } \\
(\mathrm{V})\end{array}$ & $\begin{array}{c}\text { PConductance } \\
(\mathrm{kW})\end{array}$ & $\begin{array}{c}\text { Prec.diode } \\
(\mathrm{kW})\end{array}$ & $\begin{array}{c}\text { PLosses.total } \\
(\mathrm{kW})\end{array}$ \\
\hline 160.5 & 3.3 & 4.057 & 44.14 \\
321 & 3.3 & 2.028 & 31.97 \\
493.9 & 3.3 & 1.318 & 27.70 \\
635 & 3.3 & 1.025 & 25.95 \\
645 & 3.3 & 1.009 & 25.85 \\
\hline \hline
\end{tabular}

From the Table V, it can be seen that the greater the output voltage, the losses contained in the diode will be smaller. That is because, the magnitude of the voltage is inversely proportional to the current, so that when the voltage that flows has a small value, the current flowing is relatively large.

The amount of current flowing can affect the magnitude of the power value. The amount of current flowing is directly proportional to the amount of power, this is in accordance with the equation $\mathrm{P}=\mathrm{I} 2 \mathrm{R}$. From this equation it can be seen that the amount of current flowing is squared.

With the large value of the squared current, if the current flowing already has a large value, when squared will produce a large value. The large current will then affect the amount of power in a conductor.

A graph of the relationship between the output voltage and diode losses is presented in Figure 19. 
TABLE VI

VVVF IGBT IINVERTER LOSS CALCULATION RESULTS

\begin{tabular}{cccccc}
\hline \hline \multirow{2}{*}{ Working Area } & \multicolumn{5}{c}{ Conditions } \\
\cline { 2 - 5 } & 1 & 2 & 3 & 4 & 5 \\
\hline Vout & $160.5 \mathrm{~V}$ & $321.0 \mathrm{~V}$ & $493.0 \mathrm{~V}$ & $635.0 \mathrm{~V}$ & $645.0 \mathrm{~V}$ \\
Pin Inverter & $450 \mathrm{~kW}$ & $450 \mathrm{~kW}$ & $450 \mathrm{~kW}$ & $450 \mathrm{~kW}$ & $450 \mathrm{~kW}$ \\
PLosses IGBT & $40.946 \mathrm{~kW}$ & $21.749 \mathrm{~kW}$ & $16.662 \mathrm{~kW}$ & $16.046 \mathrm{~kW}$ & $16.118 \mathrm{~kW}$ \\
PLosses diode & $44.142 \mathrm{~kW}$ & $31.968 \mathrm{~kW}$ & $27.708 \mathrm{~kW}$ & $25.950 \mathrm{~kW}$ & $25.850 \mathrm{~kW}$ \\
Plosses total & $85.088 \mathrm{~kW}$ & $53.717 \mathrm{~kW}$ & $44.370 \mathrm{~kW}$ & $41.996 \mathrm{~kW}$ & $41.968 \mathrm{~kW}$ \\
Poutput & $364.912 \mathrm{~kW}$ & $396.283 \mathrm{~kW}$ & $405.630 \mathrm{~kW}$ & $408.004 \mathrm{~kW}$ & $408.032 \mathrm{~kW}$ \\
Efficiency & $81.10 \%$ & $88.06 \%$ & $90.14 \%$ & $90.67 \%$ & $90.67 \%$ \\
\hline \hline
\end{tabular}

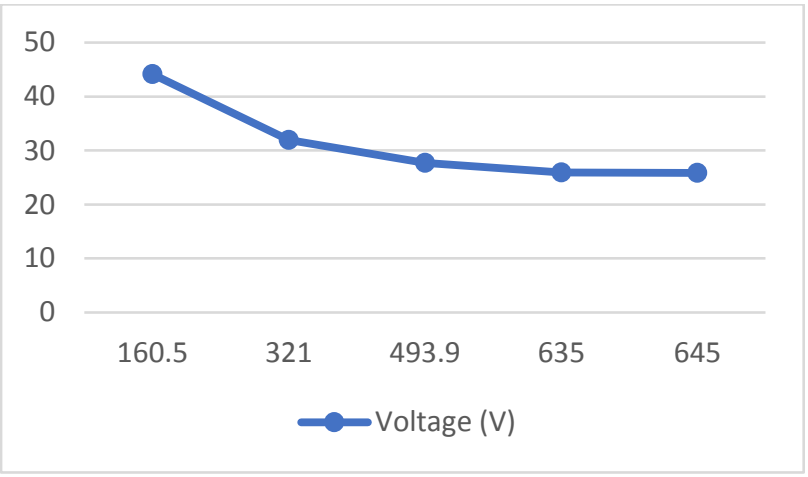

Fig. 19. A graph of the relationship between the output voltage of the inverter and the diode losses

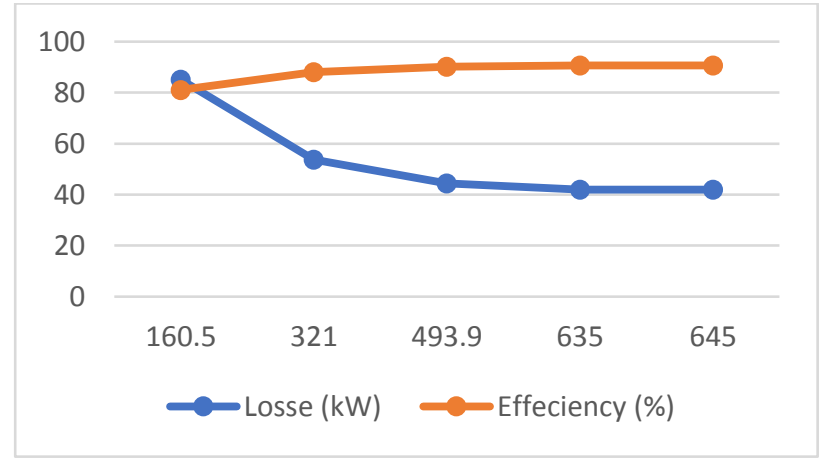

Fig. 20. Graph of the relationship between the inverter output voltage

\section{c. Total losses of IGBT VVVF Inverters}

From the Table VI, the greater the value of the output voltage, the greater the efficiency obtained. That is because, if the magnitude of the output voltage (V) The relationship between the output voltage of the inverter with the diode losses 63 the voltage that flows is small, the current that flows is large. Then to find the value of power, in the equation $\mathrm{P}=\mathrm{I}^{2} \mathrm{R}$ the amount of current flow is squared. A graph of the relationship between the output voltage and the losses and efficiency of the IGBT VVVF inverter is presented in Figure 20.

\section{Losses of Three-Phase AC}

Traction Motors Three-phase AC traction motors are the main components found in the propulsion system in KRL, which functions to convert electrical energy into mechanical energy by the principle of induction. For the system works, this motor is controlled by the VVVF IGBT inverter by changing the input voltage and frequency on the traction motor. The advantages of using this motorbike include simple form with a fairly strong construction, low cost, high efficiency, minimum maintenance and does not require special equipment when operated.

However, behind its advantages the traction motor also has power losses. The power losses are found in the stator core loss, rotor core loss, wind and friction losses, as well as other losses or what is called stray loss. After obtaining the amount of 
losses, of course, we will get how much efficiency of the traction motor.

The following is the result of the calculation of the magnitude of power losses in the traction motor with five conditions of the traction motor testing contained in the traction motor specification data, where the magnitude of the input voltage and frequency are different. With different input voltage and frequency, different results can be obtained. However, with these different results, it can be seen how the relationship between parameters with other parameters. Like the relationship of input voltage with motor efficiency, stator rotating field, rotor rotation and slip.

From the Table VII, it can be seen that the greater the value of the input voltage on the traction motor, the greater the efficiency obtained. This can occur because, when the greater the voltage that flows the current that flows will be smaller. Meanwhile, seen from the equation that the magnitude of power is the product of quadratic current multiplied by resistance or $\mathrm{P}=\mathrm{I}^{2} \mathrm{R}$, so that when the current flowing is small the current obtained is small and the value of the power is also small.

A graph of the relationship between motor input voltage and motor losses and efficiency is presented in Figure 21.

From Figure 21, the performance of the motor with the highest efficiency with an input voltage of $635 \mathrm{~V}$ with an input power of $213 \mathrm{~kW}$ and an output power of $194,781 \mathrm{~kW}$ to obtain losses of $18,219 \mathrm{~kW}$ and an efficiency of $91.45 \%$. For more details, The results of the calculation of losses contained is presented in Table VIII.

TABLE VII

The Results of Testing Five Conditions of the Traction Motor

\begin{tabular}{cccccc}
\hline \hline \multirow{2}{*}{ Working Area } & \multicolumn{5}{c}{ Conditions } \\
\cline { 2 - 6 } & 1 & 2 & 3 & 4 & 5 \\
\hline Voltage (V) & 160.5 & 321.0 & 493.0 & 635.0 & 645.0 \\
Current (A) & 247,64 & 224,40 & 217,90 & 217,60 & 197,28 \\
Pin (kW) & 59,893 & 111,04 & 165,90 & 213.00 & 191,744 \\
PLosses (kW) & 16,323 & 15,215 & 16,493 & 18,219 & 16,645 \\
Poutput (kW) & 43,570 & 95,825 & 149,407 & 194,781 & 175,099 \\
Efficiency (\%) & 72,75 & 86,30 & 90.06 & 91.45 & 91.32 \\
\hline \hline
\end{tabular}

TABLE VIII

The Results of the Calculation of Losses in Five Conditions of the Traction Motor

\begin{tabular}{cccccc}
\hline \hline \multirow{2}{*}{ Working Area } & \multicolumn{5}{c}{ Conditions } \\
\cline { 2 - 6 } & 1 & 2 & 3 & 4 & 5 \\
\hline Vin & $160.5 \mathrm{~V}$ & $321.0 \mathrm{~V}$ & $493.0 \mathrm{~V}$ & $635.0 \mathrm{~V}$ & $645.0 \mathrm{~V}$ \\
$\mathrm{f}$ & $9.10 \mathrm{~Hz}$ & $18.2 \mathrm{~Hz}$ & $28.0 \mathrm{~Hz}$ & $36.38 \mathrm{~Hz}$ & $90.0 \mathrm{~Hz}$ \\
Slip & 0.128 & 0.051 & 0.032 & 0.025 & 0.024 \\
Stator Rotational & $273 \mathrm{rpm}$ & $546 \mathrm{rpm}$ & $840 \mathrm{rpm}$ & $1091.4 \mathrm{rpm}$ & $2700 \mathrm{rpm}$ \\
Filed & $238 \mathrm{rpm}$ & $518 \mathrm{rpm}$ & $813 \mathrm{rpm}$ & $1064 \mathrm{rpm}$ & $2634 \mathrm{rpm}$ \\
Rotor Rotation & $9.138 \mathrm{~kW}$ & $8.428 \mathrm{~kW}$ & $8.985 \mathrm{~kW}$ & $9.8 \mathrm{~kW}$ & $7.219 \mathrm{~kW}$ \\
Stator Loss & $6.497 \mathrm{~kW}$ & $5.233 \mathrm{~kW}$ & $5.021 \mathrm{~kW}$ & $5.08 \mathrm{~kW}$ & $4.429 \mathrm{~kW}$ \\
Rotor Loss & $0.0238 \mathrm{~kW}$ & $0.095 \mathrm{~kW}$ & $0.227 \mathrm{~kW}$ & $0.373 \mathrm{~kW}$ & $2.33 \mathrm{~kW}$ \\
Friction Loss & $0.663 \mathrm{~kW}$ & $1.459 \mathrm{~kW}$ & $2.26 \mathrm{~kW}$ & $2.966 \mathrm{~kW}$ & $2.67 \mathrm{~kW}$ \\
Stary Loss &
\end{tabular}

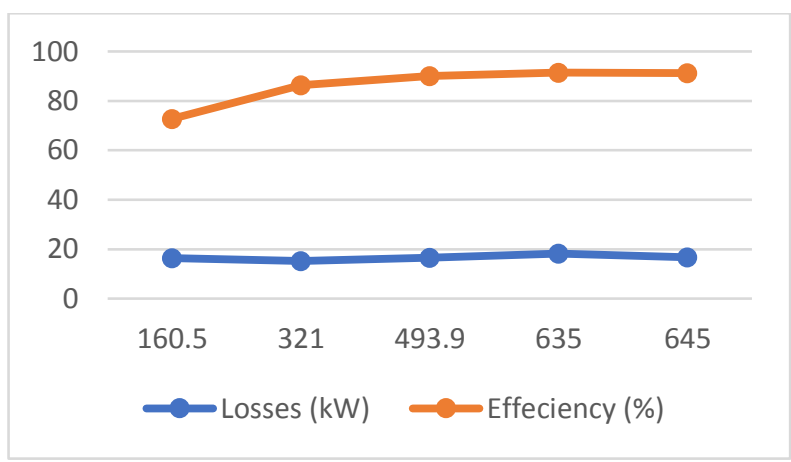

Fig. 21. Graph of the relationship between input voltage and motor losses and efficiency 
From Table VIII, with the magnitude of the input voltage and frequency that is proportional to the increase in each test, it can be seen that the greater the input voltage will produce a greater rotation, both the stator rotating field and rotor rotation. That is because the input voltage can affect the interaction between the stator magnetic field and the rotor magnetic field, where the rotor magnetic field is obtained from the induced voltage caused by the rotor coil being cut off by the stator coil. In other words, voltage and frequency are directly proportional to the number of turns of both the stator rotational field and the rotor rotation.

A graph of the relationship between input voltage, frequency, rotor rotation and stator rotational field is presented in Figure 22.

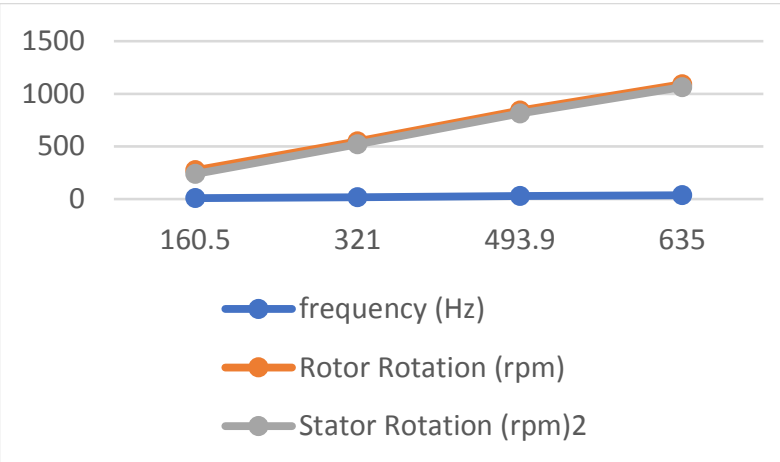

Fig. 22. Graph of the relationship between input voltage, frequency, rotor rotation and stator rotational field

The rotation of the rotor is directly proportional to the rotating field of the stator, because basically the rotation of the magnetic field on the stator is followed by the rotation of the rotor found in the induction motor. The stator rotating field is greater when compared to the rotor rotation field, this is because the rotor rotation is affected by the load. From the relationship between the two, a slip is produced which is the difference between the stator rotating field and the rotor rotation. The relationship of slip with rotation can be seen in Figure 23.

The greater the stator rotating field and rotor rotation will produce a greater slip. The slip will affect the amount of copper losses in the rotor and the frequency of the rotor current. When the rotor is at rest, the magnitude of the current frequency is equal to the source frequency, whereas when the rotor is at work the rotor frequency will be affected by slip so that the frequency at the rotor multiplied by slip is equal to the source frequency $\left(f=f_{R} \times S\right)$. This will affect the amount of copper losses in the rotor, where the amount of copper rotor losses is the result of the multiplication of the slip with the magnitude of the rotor input power.

The relationship between slip and copper rotor losses is presented in Figure 24.

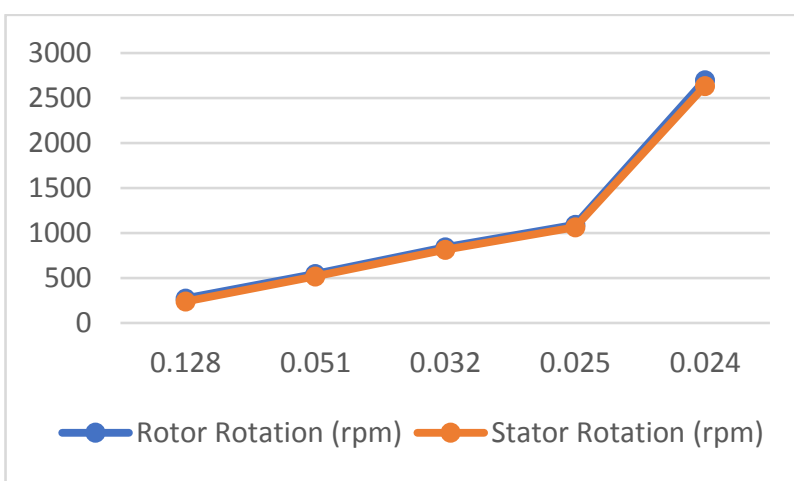

Fig. 23. Graph of the relationship between the slip with the stator rotating field and rotor rotation

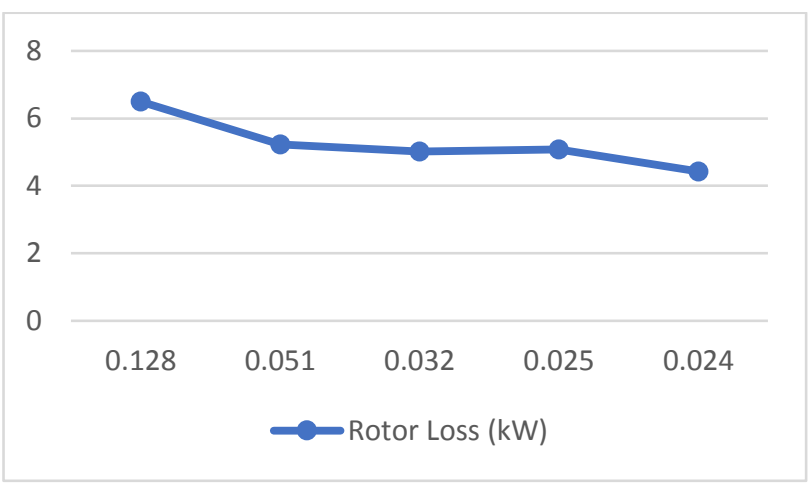

Fig. 24. Graph of relationship between slip and copper rotor loss

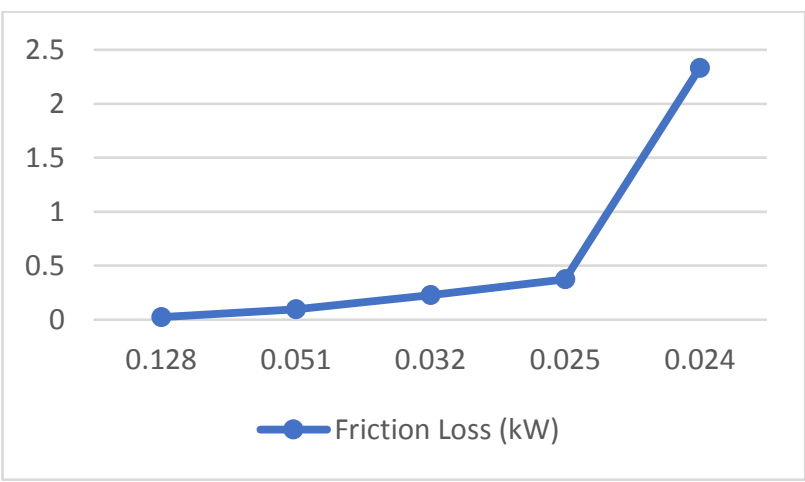

Fig. 25. Graph of relationship between rotor rotation and friction loss

Rotation of the rotor can cause friction, the friction will affect the efficiency of the motor that will cause losses called friction loss. In the results of the calculation of the traction motor losses with five conditions can be seen that the amount of 
friction loss is directly proportional to the number of rotations of the rotor.

When the rotor rotation has a large value, it will cause a large friction loss. Friction loss will increase when the rotor rotation gets bigger. This can be seen in the graph of the relationship between the number of rotations of the rotor with friction losses, both of which have a value that is directly proportional.

The relationship between rotor rotation and rotor friction loss is presented in Figure 25.

\section{Losses of Three-Phase AC}

After knowing the amount of losses contained in the IGBT VVVF inverter and AC traction motor, it will display the amount of losses and efficiency in both components contained in the propulsion system on the KRL. The magnitude of losses and efficiency in M1 and M2 cars are the same, because in this study the magnitude of the input power and load in M1 and M2 cars is assumed to be the same. Where each $\mathrm{M}$ car has two VVVF IGBT inverters, each of which controls two traction motors, so that in each $\mathrm{M}$ car there are four traction motors. For a set of KRL there are four VVVF IGBT with eight traction motors.

The results of IGBT VVVF inverter losses and AC traction motors on the KRL propulsion system with five test conditions is presented in Table IX.

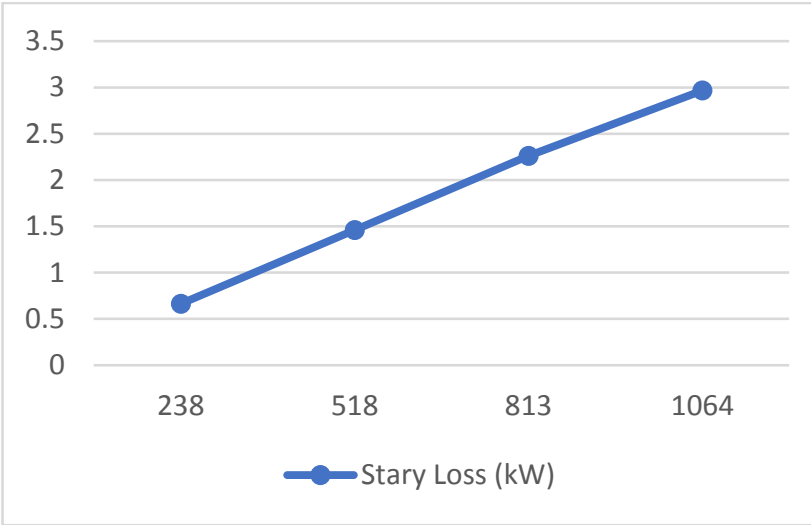

Fig. 26. Graph of the relationship between rotor rotation with stray loss

TABLE IX

The Results of Losses And EFFICIENCy in Five Test Conditions

\begin{tabular}{|c|c|c|c|c|c|}
\hline No. & Components & Pin $(\mathrm{kW})$ & $\begin{array}{l}\text { Pou } \\
(\mathrm{kW})\end{array}$ & $\begin{array}{l}\text { Ploss } \\
(\mathrm{kW})\end{array}$ & $\begin{array}{c}\eta \\
(\%)\end{array}$ \\
\hline \multirow{6}{*}{1} & VVVF IGBT Inverter 1 & 450 & 364.912 & 85.088 & 81.1 \\
\hline & VVVF IGBT Inverter 1 & 450 & 364.912 & 85.088 & 81.1 \\
\hline & Induction Motor 1 & 59.893 & 16.323 & 43.570 & 72.75 \\
\hline & Induction Motor 2 & 59.893 & 16.323 & 43.570 & 72.75 \\
\hline & Induction Motor 3 & 59.893 & 16.323 & 43.570 & 72.75 \\
\hline & Induction Motor 4 & 59.893 & 16.323 & 43.570 & 72.75 \\
\hline \multirow{6}{*}{2} & VVVF IGBT Inverter 1 & 450 & 396.283 & 53.717 & 88.06 \\
\hline & VVVF IGBT Inverter 1 & 450 & 396.283 & 53.717 & 88.06 \\
\hline & Induction Motor 1 & 111.04 & 95.825 & 15.215 & 86.30 \\
\hline & Induction Motor 2 & 111.04 & 95.825 & 15.215 & 86.30 \\
\hline & Induction Motor 3 & 111.04 & 95.825 & 15.215 & 86.30 \\
\hline & Induction Motor 4 & 111.04 & 95.825 & 15.215 & 86.30 \\
\hline \multirow{6}{*}{3} & VVVF IGBT Inverter 1 & 450 & 405.63 & 44.37 & 90.14 \\
\hline & VVVF IGBT Inverter 1 & 450 & 405.63 & 44.37 & 90.14 \\
\hline & Induction Motor 1 & 165.9 & 149.407 & 16.493 & 90.06 \\
\hline & Induction Motor 2 & 165.9 & 149.407 & 16.493 & 90.06 \\
\hline & Induction Motor 3 & 165.9 & 149.407 & 16.493 & 90.06 \\
\hline & Induction Motor 4 & 165.9 & 149.407 & 16.493 & 90.06 \\
\hline \multirow{6}{*}{4} & VVVF IGBT Inverter 1 & 450 & 408.004 & 41.996 & 90.67 \\
\hline & VVVF IGBT Inverter 1 & 450 & 408.004 & 41.996 & 90.67 \\
\hline & Induction Motor 1 & 213 & 194.781 & 18.219 & 91.45 \\
\hline & Induction Motor 2 & 213 & 194.781 & 18.219 & 91.45 \\
\hline & Induction Motor 3 & 213 & 194.781 & 18.219 & 91.45 \\
\hline & Induction Motor 4 & 213 & 194.781 & 18.219 & 91.45 \\
\hline \multirow{6}{*}{5} & VVVF IGBT Inverter 1 & 450 & 408.032 & 41.968 & 90.67 \\
\hline & VVVF IGBT Inverter 1 & 450 & 408.032 & 41.968 & 90.67 \\
\hline & Induction Motor 1 & 191.744 & 175.09 & 16.645 & 91.32 \\
\hline & Induction Motor 2 & 191.744 & 175.09 & 16.645 & 91.32 \\
\hline & Induction Motor 3 & 191.744 & 175.09 & 16.645 & 91.32 \\
\hline & Induction Motor 4 & 191.744 & 175.09 & 16.645 & 91.32 \\
\hline
\end{tabular}




\section{Conclusion}

From the research that has been done, the following conclusions are obtained:

1. From the five test conditions of the propulsion system on KRL it can be seen that the smallest losses with the greatest efficiency are in the test conditions.

2. The following is the amount of losses and efficiency of the propulsion system at KRL under test conditions:

TABLE X

LOSSES AND EFFICIENCY OF PROPULSION SYSTEMS IN KRL TESTING CONDITIONS

\begin{tabular}{ccc}
\hline \hline Components & Losses (kW) & Effeciency (\%) \\
\hline VVVF IGBT Inverter & 41.996 & 90.67 \\
AC Traction Motor & 18.219 & 91.45 \\
\hline \hline
\end{tabular}

\section{Acknowledgements}

This work was supported by Universitas Muhammadiyah Yogyakarta.

\section{References}

[1] J. Wang, Z. Yang, F. Lin, and J. Cao, "Harmonic loss analysis of the traction transformer of highspeed trains considering pantograph-OCS electrical contact properties," Energies, vol. 6, no. 11, pp. 5826-5846, 2013.

[2] A. E. Setiawan, T. Odinanto, and S. Muharom, "Rancang Bangun Inverter 3 Fasa sebagai Pengendali Kecepatan Motor Induksi 3 Fasa 1/2 HP $0.37 \mathrm{~kW}$ menggunakan Metode SPWM berbasis ARM Mikrokontroler (STM32F4)," Jur. Tek. Elektro, Institiut Teknol. Adhi Tama, Surabaya, pp. 17-24, 2016.

[3] S. Corino, E. Romero, and L. F. Mantilla, "How the efficiency of induction motor is measured?," Renew. Energy Power Qual. J., vol. 1, no. 6, pp. 530-534, 2008.

\section{AUTHORS' INFORMATION}

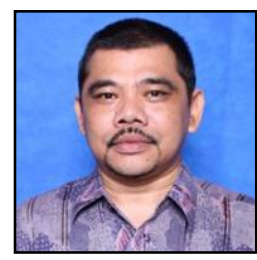

Agus Jamal obtained his B. Eng in Electrical Engineering from Universitas Gadjah Mada, Indonesia in 1994. His Master study was done at 2010 at the Electrical Engineering, Universitas Gadjah Mada, Indonesia. He currently is a lecture in department of electrical engineering, Universitas Muhammadiyah Yogyakarta.

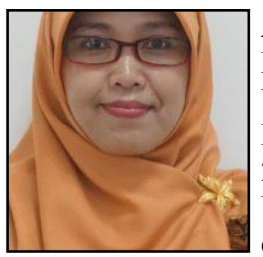

Anna Nur Nazilah Chamim obtained her B. Eng in Electrical Engineering from Universitas Muhammadiyah Yogyakarta, Indonesia. Her Master study was done at 2015 at the Electrical Engineering, Universitas Gadjah Mada, Indonesia. She currently is a lecture in department of electrical engineering, Universitas Muhammadiyah Yogyakarta.

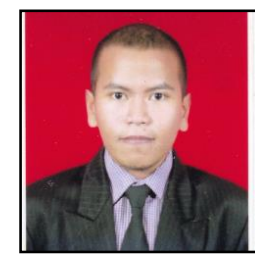

Karisma Trinanda Putra obtained his B. Eng in Electrical Engineering from Institut Teknologi Sepuluh Nopember, Indonesia in 2012. His Master study was done at 2015 at the Electrical Engineering, Institut Teknologi Sepuluh Nopember, Indonesia. He currently is a lecture in department of electrical engineering, Universitas Muhammadiyah Yogyakarta.

Sri Indah Lestari obtained her B. Eng in Electrical Engineering from Universitas Muhammadiyah Yogyakarta, Indonesia in 2018 .

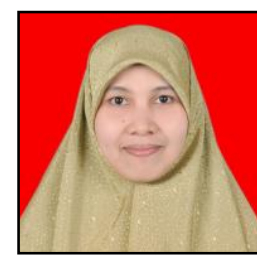

Yessi Jusman obtained her B. Eng in Electrical and Electronic Engineering from Andalas University, Indonesia in 2007. She worked as a Research Assistant started in July 2008 until November 2009 in Universiti Sains Malaysia. Her Master study was done at 2012 at the School of Electrical and Electronic Engineering, USM Engineering Campus in Nibong Tebal, Penang, Malaysia. She was finished her $\mathrm{PhD}$ degree at 2016 in University of Malaya with specializes in Image, Signal Processing, and algorithms. 